\title{
Cope with Stress in Manager Life ${ }^{1}$
}

\section{Summary}

The article deals with stress mainly in managerial positions. Stress is much extended in all aspects of our life and employment is an important factor which increases the level of stress. Managers have specific place between other occupations. At first the paper describes the most frequent stressors generally and kinds of coping stress methods. Then there are introduced some groups of stressors which are more frequent in managerial positions. The paper is closed by preventive methods of coping stress.

\section{Introduction}

Stress is always omnipresent. People are not allowed to live without stress. On one hand there is a lot of stressors and on other hand, some level of stress is necessary to life. Managers along with other occupation where is permanent contact with people, are jeopardize by stress. In this article I want to have a look more closely to stress in managerial positions and to its coping. Because a number of managers increase away it could be good to know which stress factors are the most frequent and how managers can defend from this factors. Excessive load begets not only total emasculation of (Hřibová, 2003).

* Dr, Department of Economics and Management of Chemical and Food Industry, Institute of Chemical Technology Prague, Czechy.

${ }^{1}$ This article is published as the part of research intention MSM 6046137306. 


\section{Stressors}

„Stressor can be any factor which brings about some psychical or physical load“. It is not a definition of stress but I think this sentence is very apposite. That is to say stress begets both negative and positive factors (Praško, 2007; Křivohlavý, 1994). Load is not only illness or loss of employment but also win in a lottery or acquirement a new prettier office.

Leverage of stressors adds up in time continuance and therefore are harmful also micro-stressors, which separately do not cause to happen a stress reaction and very often we do not appreciate their leverage (Koukal, 2005; Křivohlavý, 1994).

Stressor starts in organism biological reaction. Primarily a stress was jeopardy, therefore these reactions prepared organism to attack or escape. Owing to stress are loose hormones adrenalin a noradrenalin and also endorphins from brain to silence pain. After it are loose also sugars to blood. This energy is oriented to most important parts of human body to attack or escape, it means brain, muscles, heart and bellows. Breath and pulse are faster, muscles are more tensed. Other systems especially blood vessels in derma have narrow blood supply (Trojan, 1999).

If it is emergent stress than after stressors incidence incoming phases of resistance and release. The body loosens adenocorticotrop hormone and cortisone to rend proteins and complex sugars to monosugars.

A problem is if the incidence of stressors is. The phase of resistance is not suitable and stress reaction increases. In extreme cases can start grand difficulties (Nakonečný, 2000). The reaction to stressor is not influenced only by its objective intensive, but especially by subjective perception of stressor. One research in USA (Koukal, 2005) tell a man is each day contact by circa 400000 different stressors. It is about one thousand times more than before 100 years.

Influence to coping has intelligence, self-confidence, topical health and peace in social relationships. Employers in some posts are moreover trained to certain types of stress but in managerial positions are training to coping meanwhile not used.

A lot of time we spend in family and in work and therefore are stressors from these areas the broadest stressors. In the family stress arises from bad function communication, from negative emotions (also not manifested) from incongruity in sexual life etc. Employment sometimes brings physically exigent work, existential fears and a lot of stress arises from bad communication. Managers are in frequent contact with people and therefore there is communication very important factor in this group.

Two other groups are stressors which result from life style and from illnesses and handicaps. Nowadays a lot of people work in sedentary occupation and our organism is not good adapted to it, we often eat unhealthy meals, we sport few, do not respect biorhythms etc. Managerial work is influenced by stressors from all four these groups, of course. 


\section{Coping strategies}

As coping methods are for this article denoted ways how to minimize harmful consequences of stress. It is possible by restriction topical stressors, better adaptation to these stressors and (the best) by combination of both these ways.

\subsection{Methods for restriction stressors}

It is not possible to totally eliminate all stressors and some level of stress is even necessary for organism. In the cases in which are to much stressors we can (for restriction of their influence) use for example:

- Time management - methods how to organize own work time by sorting out tasks, creating archive system, system to warning to tasks' terms etc. Time management can by used to restrict procrastination. We all do not like some activities and often we linger they out. Because the unpleasant activities are generally even more unpleasant if we fill them late, using Time management can stress dramatically restrict (Botek, 2007).

- Method 5S - these methods is used particularly in production to creating and keeping order and elimination needless activities.

- Creation of clear rules - because stress often arises from uncertainty and impossibility to anticipate results of own activity, creation of rules is way which can stress relevantly restricted.

\subsection{Methods of coping stress}

In the literature we can find a number of different methods how to adapt to stress or how to decrease its negative symptoms. In my article I try to summarize these methods to five groups:

- Physical activities - they serve primarily for reduce adrenalin which is produced in stress. They also help to improvement health condition, to better life style and relaxation.

- Relaxing techniques - their task is to cause to people's psyche and the goal is to release tension. Some of them need specialist to learn the method (eg. Progressive muscle relaxation, cranial electro-stimulation, autogenic training), some method are more simply (Provazník, 2006; Tyl, 2003b). To this group can by submit also yoga or meditation.

- Psychological methods - are wide group of methods which need (at least in rehearsal) help of psychologist. They concern to alleviator or elimination of stress by elimination of reasons, by help to understand these reasons or teach better compensation techniques to coping stress.

- Temporary and dangerous methods - techniques which bring almost immediate but only short-term decreasing stress. Moreover they easy can develop into dependence and inordinate using of these methods can lead to psychical problems. Methods from this group are alcohol, medicaments, cigarettes and other drugs. 
- Defensive mechanisms - are ways to adapt to stress which are innate. It is instinctive defense before load which we are not able to manage. These techniques are readjusted by upbringing to be social accepted but in spite of it they are not suitable to coping stress. Typical defense mechanisms are aggression and escape (real physical aggression and escape or verbal violence and escape to so-called internal world), attract of attention, rationalization (searching rational explanation of no logical behaviour), regression (a backdown to techniques used in former development periods), suppression (displacement negative ideas from consciousness; but these ideas onward affect in non-consciousness and they can create phobias), compensation (effort to align a failure in one activity by success elsewhere) (Clark, 1998; Baumeister, Dale, Sommer, 1998).

\section{Stress in manager life}

To specify all stressors which can influence manager is not possible. Item it is impossible to find only a few methods to cope the stress. Work of manager is so much heterogeneous than stressor can by in principle anything. One the other hand, each manager can prefer his own method to cope stress. But we can create basic groups from "similar" stressors.

\subsection{Stressors from normal life}

Managers are people, of course and therefore they are influenced by lots stressors from normal situation. They can be bad health, problems in family life, absence of sleep and many other stressors.

\subsection{Stressors from working life}

I would like to specify the most often stressors, particularly in middle and low management. It is possible to create a few groups of usual "work" stressors:

a) Dealings to people - all managers have to very often negotiate with people. They can be suppliers, clients, business partners, subordinates, colleagues or superiors. In some cases it is necessary as much as possible submit of client's requests, in other cases managers have to assert their opinions (in relation to subordinates, suppliers). Very often is used compromise behaviour (in dealings to all previously say).

b) Large responsibility - especially on higher posts are managers responsible for produces of their subordinates. Because people can not be managed like machines, managers have to believe them. In a bigger rate it is in Supply Chain management where employees from different businesses cooperate.

c) Great amount of tasks - managers usually coordinate the work of other people thus they oversee to fulfilment of tasks but they also have their own tasks. If they not only check tasks their subordinates but also repair or complete the work they can not bring off all tasks in normal work time. The result is lack of free time and excessive exhaustion. 
Secondary is the result also deterioration relationships in family and to friends because manager can not go in for them.

d) Frequent conflicting goals - a lot of managers' tasks (goals) contradict mutually. A frequent goal - decreasing of costs - is sometimes supplemented by requirement alongside to increase the market share (which is impossible without investment) or by request to expand product's assortment or to purchase a new technology.

e) Time stress - each manager has number of terms to finish some task. A part from these terms is not accomplishable, other conversely can be too effortless and conclusion of many can be a few days shift. If manager has tendencies to procrastination and he does not handle Time management terms are very important stressors.

f) Solution of topical crises - this stressor can also relate with non-performance of terminus but here it is particularly necessity to solute acute, unexpected „crash“ which can be bad quality of product, mistake in accounting, illness an important employer, nondelivery ordered raw material etc.

g) Dependence on non-suggestible decisions - particularly managers in lower posts are depended in decisions of top management which they have to accept. All employees in the firm have to accept laws, notices or government degrees and European Union degrees, of course. Impossibility to change these decisions and often also their rapid changes can lead to frustration.

\section{Possibilities to restrict stress}

These load situations are usual and all managers sure know some was how to manage them. If they are not only defensive mechanisms, medicaments or drugs, it is possible to use them with success. In this article I would like to introduce a few techniques which can be an asset to portfolio of anti-stress arsenal:

a) Regular sport activities - managerial work is usually time exigent and manager has to be much time seated. Regular exercise both develops life style and it is prevention before illness. Physical active man better manage also psychic load.

b) Punching ball, squash - the most rapid way how to reduce washed-up adrenalin is intensive physical activity. In Japan they have in the firms rooms in which any employee can beat to dummy of boss. In our condition is for reducing adrenalin often get-at-table squash or basketball in lunch break or it is possible to go bang to punching ball or to kick to wall in neighboring sound isolated room (in the case of topical stress).

c) Time management - techniques of Time management help correctly arrange the tasks, create order and reduce procrastination.

d) Delegating of tasks - no manager can in good quality bring off all tasks which he should to do. Some of them it is necessary to delegate - to depute them to subordinates. Correctly tasks' delegating decreases time stress and make possible also career development and increasing of employees' motivation.

e) Communication skills training - it is very important to all managers but mainly to managers which regard public manner and dealings with people as a strong stressor. 
f) Assertivity training - it is again suitable mainly to all managers because assertivity aids suitable self-promotion and also deprecating of non-accomplishable requests without guilt feelings.

g) STOP technique - stopping of undesirable ideas is suitable by fears from received task, by fear from failure but also by divergent thoughts in deliberation. Training this method is suitable to do with psychologist's help and order STOP has to be at first said really aloud. If you master this technique, it is enough thought direction STOP.

h) Positive stimulation - the effort to find in each situation their better points and positive connotation (positive description of situation) helps decrease intensity of impacting stressor. For example in the case of crash in apparatus it is possible „cry“ at formed damage and dread to reaction our superiors, customers and public or to inform public about our good preparation to reaction to this crash and about small danger for locality. It is possible to understand this crash as a tragedy or also as a chance to finally buy new more ecological and economic apparatus, to sell stocks and to avoid a solution a complicated dilemma if to produce non-ecological and pay penalties or to invest to more expensive new apparatus.

i) In the case of relevant stress which starts to threaten health or psychic peace it is necessary to seek professional psychological help.

\section{Conclusion}

Manager is a man who meets a lot of stressors, not only in his own life but in his work life, too. This occupation is characteristic by contact and cooperation with people, by large responsibility, time stress, etc.

Some of us have good ability to cope stress, but managers should learn also other coping techniques. They can use not only simple ones (e.g. do sport, live healthy, relax). There are a lot of other methods to cope stress. One of them is Time management, because time stress is nowadays much extended. Other techniques can help manager to decrease anxiety about contact with people (especially speech in face of a group of people is often stressful).

In this article, created as a part of research intention Nr. MSM 6046137306, are intimated some possibilities, how to restrict stress. Their effective encompassment and using however call for training and repetition and sometimes also by help from expert (psychologist). Such investment of time and power pay of it not only for managers.

\section{References}

Baumeister R.F, Dale K. and Sommer K.L. Freudian, Defense Mechanisms and Empirical Findings in Modern SocialPsychology: Reaction Formation, Projection, Displacement, Undoing, Isolation, Sublimation, and Denial, "Journal of Personality" 66, 1998.

Botek M., What solves the IV. generation of Time management, "Moderní řizení" 10, 2007. (in Czech)

Clark A.J., Defense Mechanism in the Counselling Process, Sage Publications, 1998. 
Hřibová M., Comparison of stress load in nurses, Bachelor work, Brno: Masaryk univerzity, 2003 (in Czech)

Koukal M., Die, you eschew the stress (in Czech) http://www.21stoleti.cz/view.php?cisloclanku= 2005102104 last update 2005 cited 16.9. 2007

Křivohlavý J., How to manage the stress, Grada Avicenum, Praha 1994 (in Czech)

Nakonečný M., Human emotion, Avicenum, Praha 2000. (in Czech)

Praško J., Excessive fears about health, Portál, Praha 2004 (in Czech)

Provazník K., Manual of prevention in med practise http://www.zdravcentra.cz/cps/rde/xchg/zcsk/xs1/ 3141_2255.html last update 2006 cited 16.9. 2007 (in Czech)

Trojan S., Medical physiology, Grada Avicenum, Praha 1994 (in Czech)

Tyl J., Method of cranial electro stimulation http://www.eegbiofeedback.cz/e-stim/cesky/cesky.php? menu=popismet last update 2003 cited 16.9. 2007, 2003b

\section{Sposoby radzenia sobie ze stresem przez menedżerów}

\section{Streszczenie}

Artykut zajmuje się stresem na stanowiskach kierowniczych. Stres wystęuje we wszystkich aspektach życia człowieka, a praca jest głównym czynnikiem zwiększajacym jego poziom. Praca menedżerów obciązona jest natomiast stresem w największym stopniu. W pierwszej części artykuł opisuje podstawowe rodzaje stresu i sposoby radzenia sobie z nim. Na tej podstawie wyróżniono następnie główne czynniki stresotwórcze w pracy menedżerów. Artykuł kończy charakterystyka metod ograniczania stresu w pracy zawodowej kadry kierowniczej. 